ferent pedagogical techniques, oriented at efficient support of the didactic communication in the situations of educational interaction, have been analysed. The following 12 groups of teachers have been distinguished: controlling (with extremely high level of stereotypisation) - 14 respondents, differential (the one with extremely high level of stereotypisation) - 40 respondents, facilitative (with extremely high level of stereotypisation) - 21 respondents; controlling (with high level of stereotypisation) - 8, differential (with high level of stereotypisation) - 30, facilitative (with high level of stereotypisation) - 7; controlling (with normal level of stereotypisation) - 8, differential (with normal level of stereotypisation) -27 , facilitative (with normal level of stereotypisation) - 6; controlling (with low level of stereotypisation) - 7, differential (with low level of stereotypisation) - 27, and facilitative (with low level of stereotypisation) - 10 respondents. The obtained results make it possible to conclude that the pedagogues with very high stereotype tendencies have difficulties associated with the violations of emotional stability, motivational complex and self-image. Under the conditions of crisis states, the group of teachers with the facilitative type is considered to be optimal according to psychological characteristics. The group of the controlling type is characterised by emotional ill-being, insufficient satisfaction with work, etc. With the decrease of the corresponding stereotype tendencies the processes of self-organisation, identification and stereotypisation become interconnected.

Keywords: pedagogical activities, educational process, pedagogical stereotypes, transformation, development.

Рецензент: д. психол. н., проф. П. В. Лушин

Подано до редакиії 07.11.2016

UDC: $159.9+654-026.26$

Oleksii Chebykin,

Doctor of Psychology, professor, academician, South Ukrainian National Pedagogical University named after K. D. Ushynsky, 26, Staroportofrankivska Str., Odesa, Ukraine

\title{
PSYCHOEMOTIONAL DEPENDENCE ON MEANS OF MOBILE COMMUNICATIONS IN STUDENTS WITH DIFFERENT DEMONSTRATIONS OF EMOTIONAL MATURITY
}

The paper presents the study of students' psychoemotional dependence on mobile means of communications. It has been found that $22 \%$ of the surveyed students have high level of dependence, $47.5 \%$ - the medium one, and $30.5 \%$ - the low one. The students with different levels of dependence are characterised by significant differences in the peculiarities of emotional maturity. The indicators of emotional maturity are empathy, self-regulation and its integral indicator. The results obtained can be employed in prophylactic treatment and correction of students' psychoemotional dependence on mobile means of communications.

Keywords: psychoemotional dependence, mobile means of communications, students, emotional maturity.

\section{Introduction}

In recent years, mobile phones, smartphones and other similar means of communication have become extremely popular, especially with young people. According to the latest research, the vast majority of specialists are working on the development of new and modernisation of the existing means of mobile communications. However, only few scientists investigate psychological aspects of their impact on various functions of the human psyche $[2 ; 6 ; 8$, and others]. Generalisation of these research works demonstrates that excessive use of mobile communication means has ambiguous impact on different functions of the psyche, including emotional sphere of a developing personality.

Our previous research works [4] demonstrate that young people who widely use various media may have psychological dependence that disorients their emotional states and is difficult to overcome. It is assumed that similar phenomena take place in interaction with smartphones that are being used with an increased frequency. With this in mind, the aim of the paper is to study the peculiarities of students' emotional spheres taking into consideration the specificity of their use of mobile means of communications in everyday life.

Some contemporary research works on psychology $[5 ; 7]$ present the studies on different aspects of impact of the media on certain psychological peculiarities of people. These studies attempt to investigate the influence of mobile phones (smartphones) on certain psychophysiological functions, find out the specific character of their use depending on gender, ethnic or other peculiarities. At the same time, the issue of psychoemotional dependence on mobile phone remains understudied. In this context, particularly relevant is the issue of using mobile communication means by young people with different peculiarities of emotional maturity development. It is known that pecu- 
liarities of emotional sphere may indicate personality's dependence on various factors.

The aim of the paper involved the solving of the following problems: firstly, to develop the technique for the most integrated and comprehensive investigation of two aspects of students' dependence on mobile communication means; secondly, to identify the level of dependence on mobile communication means in students with different demonstrations of emotional stability. The fundamental hypothesis involves supposition that emotional maturity reflects certain dependence of a personality to the fullest extent due to being integrated with almost all psychological demonstrations.

\section{Discussion}

Summarising the research results, we have developed a questionnaire that made it possible to identify various peculiarities of students' use of mobile means of communication [1]. Generally, the questionnaire was used to elicit and evaluate the indicators represented at the following conventional scales: communicative, motivational, conative, cognitive and the scale of dependence on mobile means of communication. Emotional maturity was investigated by means of the technique [3] that made it possible to identify and evaluate the major components of emotional maturity: expressiveness, empathy, selfregulation and its integrative component.

The empirical part of the study was carried out among 200 students aged 17-20 years different in sex, the level of training, and country of studying. The results of the study demonstrated that according to the level of dependence, all the examined students could be classified into three groups: students with the high (22\%, Group 1), medium (47.5\%, Group 2) and low level of dependence (30.5\%, Group 3).

Based on the results obtained, further analysis was carried out with aim of identifying the differences between students in terms of dependence on mobile phones (smartphones), characteristics of the major component of emotional maturity and in general.

According to the analysis of preliminary and mean values of the diagnosed characteristics of emotional maturity (Picture 1), there are some differences between the groups of students, especially between the ones with the high dependence level and others.

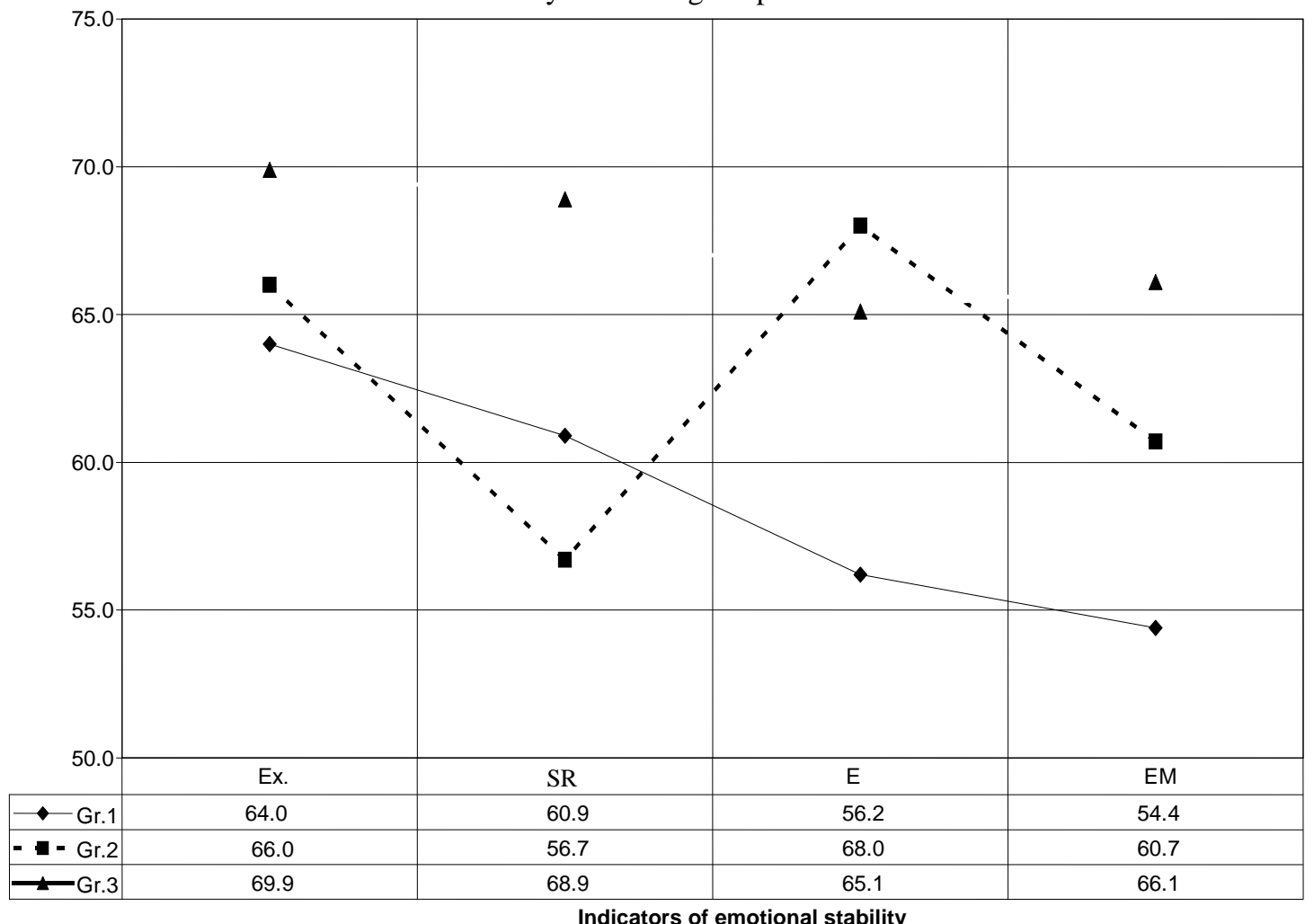

Picture 1. Mean values of the indicators characterising emotional maturity students with different use of mobile means of communication

Note: Ex - expressiveness, SR - self-regulation, E - empathy, EM - emotional maturity

Further analysis has shown that in students with high and medium levels of dependence on mobile means of communications, there are statistically significant differences in terms of empathy $(\mathrm{t}=2.15, \mathrm{p}<0.5)$, self-regulation and integral indicator of emotional maturity $(\mathrm{t}=2.02, \mathrm{p}<0.5)$. In addition, significant differences between the students with high and low levels of dependence on mobile phone (smartphone) were found in terms of emotional maturity demonstration. In the latter case, it is referred to the characteristics 
of self-regulation $(\mathrm{t}=2.0, \mathrm{p}<0.5)$ and integral index of emotional maturity $(\mathrm{t}=2.0, \mathrm{p}<0.5)$ (Table 1$)$.

Besides, similar statistically significant differences between the characteristics of emotional maturity were identified when comparing students with the low and medium level of dependence. In this case, it is referred to self-regulation indicators $(\mathrm{t}=2.53, \mathrm{p}<0.01)$ and integral indicator of emotional maturity $(\mathrm{t}=1.99, \mathrm{p}<0.5)$.

Table 1.

Statistically significant differences of emotional maturity indicators between the groups of students with different levels of dependence on mobile means of communications

\begin{tabular}{|c|c|c|c|c|c|}
\hline $\begin{array}{l}\text { Level of depen- } \\
\text { dence }\end{array}$ & Statistical indicator & Expressiveness & Self-regulation & Empathy & $\begin{array}{l}\text { Emotional } \\
\text { maturity }\end{array}$ \\
\hline \multirow{2}{*}{ High } & $\mathrm{x}$ & 7.32 & 6.42 & 6.77 & 20,51 \\
\hline & $\sigma$ & 2.47 & 2.43 & 1.90 & 5,44 \\
\hline \multirow{2}{*}{ Medium } & $\mathrm{x}$ & 7.7 & 6.9 & 8.93 & 23,57 \\
\hline & $\sigma$ & 1.7 & 2.2 & 2.02 & 3,012 \\
\hline & & - & - & $\begin{array}{l}t=2,15 \\
p<0,05\end{array}$ & $\begin{array}{l}\mathrm{t}=2.02 \\
\mathrm{p}<0.05\end{array}$ \\
\hline \multirow{2}{*}{ High } & $\mathrm{x}$ & 7.32 & 6.42 & 6.77 & 20,51 \\
\hline & $\sigma$ & 2.47 & 2.43 & 1.90 & 5,44 \\
\hline \multirow{2}{*}{ Medium } & $\mathrm{x}$ & 7.33 & 7.82 & 8.20 & 23,35 \\
\hline & $\sigma$ & 2.00 & 2.10 & 2.02 & 4,63 \\
\hline & & - & $\begin{array}{l}t=1,99 \\
p<0,05\end{array}$ & - & $\begin{array}{l}\mathrm{t}=2.18 \\
\mathrm{p}<0.05\end{array}$ \\
\hline \multirow{2}{*}{ High } & $\mathrm{x}$ & 7.33 & 7.82 & 8.20 & 23,35 \\
\hline & $\sigma$ & 2.00 & 2.10 & 2.02 & 4,63 \\
\hline \multirow{2}{*}{ Medium } & $\mathrm{x}$ & 7.7 & 6.9 & 8.93 & 23,57 \\
\hline & $\sigma$ & 1.7 & 2.2 & 2.02 & 3,01 \\
\hline & & - & $\begin{array}{l}\mathrm{t}=2.53 \\
\mathrm{p}<0.01\end{array}$ & - & $\begin{array}{l}\mathrm{t}=1.99 \\
\mathrm{p}<0.05\end{array}$ \\
\hline
\end{tabular}

The comparison of the peculiarities of emotional maturity expressiveness in students with difference level of mobile phone use makes it possible to note that students who consider their mobile phones/smartphones as their "best friend" use it mostly for communication or as a source of necessary emotions (high level of dependence). They are characterised by much lower empathy and ability for self-regulation compared to the students who prefer face-to-face communication and use their mobile phones/smartphones only as needed (i.e. have low level of dependence).

Fundamental correlation analysis of the indicators of emotional maturity and dependence made it possible to establish certain relations. For example, in the group of students with the high level of dependence, the corresponding indicator correlates with self-regulation $(\mathrm{z}=$ $0.302 \mathrm{p}<0.01)$ and integral indicator of emotional maturity $(\mathrm{z}=-0.315 \mathrm{p}<0.01)$. In the group of students with the medium level of dependence, similar relations were stated with the integral indicator of emotional maturity $(\mathrm{z}=-$ $0.210 \mathrm{p}<0.05)$ and empathy indicators $(\mathrm{z}=-0.306 \mathrm{p}<0.01)$. In the group of students with the low level of dependence, only the integral indicator of emotional maturity correlates with the corresponding indicator of dependence level $(\mathrm{z}=-0.305 \mathrm{p}<0.05)$.

These results may indicate that students with the high and medium levels of dependence are very sensible in demonstrating the main components of emotional ma- turity and its general level. In this case, it has been found that changes in self-regulation and emotional maturity in general may intensify or reduce the level of dependence on mobile means of communication. Almost the same situation was observed in the group of students with the medium level of dependence, where the general level of emotional maturity and empathy may cause similar changes in dependence level. As for the students with the low level of dependence, their integral indicator of emotional maturity has positive correlation with dependence level. The latter can be explained by the fact that balanced level of emotional maturity development contributes to optimal and pragmatic use of a mobile phone/smartphone.

In addition, it should be mentioned that the students with the high level of dependence of mobile means of communications are characterised by insufficient emotional stability, poor capability for emotional regulation and corresponding empathy. As previously noted, the changes in these characteristics may intensify or reduce the level of dependence. For this reason, it is important to take them into consideration when developing proper systems of psychological prophylactic treatment and correction of students' dependence on mobile means of communications.

\section{Conclusions}

Therefore, the following conclusions can be drawn.

1. The issue of students' psychological dependence on mobile means of communications is rather relevant in 
the context of their broadening use. Most experts study the level of impact of mobile phones/smartphones' physical properties and some psychological differences.

2. It has been shown that the peculiarities of emotional maturity of a developing personality may indicate its dependence on mobile means of communications.

3. Students demonstrated high (22\%), medium $(47.5 \%)$, and low $(30.5 \%)$ levels of dependence on mobile means of communications.

4. It has been proven that the indicators of emotional stability of students with different level of depend-

\section{ЛІТЕРАТУРА}

1. Кабешева А. О. Про взаємозв'язки показників, що характеризують особливості використання мобільного телефону з властивостями особистості студентів / А. О. Кабешева // Актуальні проблеми психології : Збірник наукових праць Інституту психології імені Г. С. Костюка : Психологія особистості. Психологічна допомога особистості. - Київ, 2014. - Том.11. Вип. 13. - С. 240-246.

2. Михайлов Д. В. Психологические и физиологические аспекты влияния мобильных телефонов на человека [Электронный ресурс] / Д. В. Михайлов, Ю. С. Тучина. - Режим доступа : http://www.sworld.com.ua.

3. Чебикін О. Я. Становлення емоційної зрілості особистості : [монографія] / О. Я. Чебикін, І. Г. Павлова. - Південний науковий центр АПН України. Одеса : СВД Черкасов, 2009. - 232 с.

\section{REFERENCES}

1. Kabesheva, A. O. (2014). Pro vzaiemozviazky pokaznykiv, shcho kharakteryzuiut osoblyvosti vykorystannia mobilnoho telefonu $\mathrm{z}$ vlastyvostiamy osobystosti studentiv [About correlations of indicators characterizing the peculiarities of mobile phone use and students' personal qualities]. Aktualni problemy psykholohii: Zbirnyk naukovykh prats Instytutu psykholohii imeni H. S. Kostiuka: Psykholohiia osobystosti. Psykholohichna dopomoha osobystosti - Topical issues of psychology: Collection of scientific papers of H. S. Kostiuk Institute of Psychology: Personality psychology. Psychological aid, 13, 240-246. (Vols. 11). Kyiv [in Ukrainian].

2. Mikhaylov, D. V., \& Tuchina, Yu. S. (n.d.). Psikhologicheskie $i$ fiziologicheskie aspekty vliyaniya mobilnykh telefonov na cheloveka [Psychological and physiological aspects of mobile phones' impact on people]. Retrieved from: http://www.sworld.com.ua [in Russian].

3. Chebykin, O. Ya., \& Pavlova, I. H. (2009). Stanovlennia emotsiinoi zrilosti osobystosti [The development of personality's emotional maturity]. Odesa: SVD Cherkasov [in Ukrainian]. ence on mobile means of communications have certain distinctions that are statistically different in the groups. The indentified correlation relations indicate that the integral indicator of emotional maturity as well as its components (self-regulation and empathy) in students with the high and medium levels of dependence on mobile phones/smartphones are of importance for developing appropriate system of prophylactic treatment and correction.

4. Чебикін О. Я., Кримова Н. О. Вплив комп'ютерної діяльності на емоційну сферу студентів / О. Я. Чебикін, Н. О. Кримова // Наука і освіта. 2015. - №3 / CXXXII. - C. 126-133.

5. Янг К. С. Диагноз - Интернет-зависимость / К. С. Янг // Мир Интернет. - 2000. - № 2. - С. 24-29.

6. Bianchi Adriana, Phillips James G. CyberPsychology \& Behavior [Електронний pecypc] / Adriana Bianchi, James G. Phillips. 2005. - 8(1). - C. 3951. doi:10.1089/cpb.2005.8.39. - Режим доступа : http://online.liebertpub.com/doi/abs/10.1089\%2Fcpb. 2005.8.39.

7. Griffiths M. Internet addiction : Fact or fiction? / M. Griffiths // Psychologist. - 1999. - V. 12(5). - P. 246-250.

8. Haddon L., Vincent J. Children's Broadening Use of Mobile Phones. Mobile Technologies from Telecommunications to Media / L. Haddon, J. Vincent. New York. - 2009. - P. 37-49.

4. Chebykin, O. Ya., Krymova, N. O. (2015). Vplyv kompiuternoi diialnosti na emotsiinu sferu studentiv [The influence of computer activity on students' emotional sphere]. Nauka $i$ osvita - Science and education, 3/CXXXII, 126-133 [in Ukrainian].

5. Yang, K. S. (2000). Diagnoz - Internet-zavisimost [Diagnosis: Internet addiction]. Mir Internet - World Internet, 2, 24-29 [in Russian].

6. Bianchi, A., \& Phillips, J. G. (2005). CyberPsychology \& Behavior. doi:10.1089/cpb.2005.8.39. Retrieved from: http://online.liebertpub.com/doi/abs/10.1089\%2Fcpb. 2005.8.39 [in English].

7. Griffiths, M. (1999). Internet addiction: Fact or fiction? Psychologist, 12(5), 246-250 [in English].

8. Haddon, L., \& Vincent, J. (2009). Children's Broadening Use of Mobile Phones. Mobile Technologies from Telecommunications to Media. (pp. 37-49). New York [in English]. 
Алексей Яковлевич Чебыкин, доктор психологических наук, профессор, академик, Южноукраинский национальный педагогический университет имени К. Д. Уиинского, ул. Старопортофранковская, 26, г. Одесса, Украина

\section{ПСИХОЭМОЦИОНАЛЬНАЯ ЗАВИСИМОСТЬ ОТ СРЕДСТВ МОБИЛЬНОЙ СВЯЗИ У СТУДЕНТОВ, ИМЕЮЩИХ РАЗЛИЧНЫЕ ПРОЯВЛЕНИЯ ЭМОЦИОНАЛЬНОЙ ЗРЕЛОСТИ}

Статья посвящена проблеме психоэмоциональной зависимости студентов от мобильных средств связи. Автор исходил из следующей гипотезы: поскольку эмоциональная зрелость личности является интегральным свойством, которое интегрируется фактически со всеми особенностями психики, она в наибольшей степени будет характеризовать наличие той или иной психоэмоциональной зависимости. Для исследования особенностей зависимости студентов от использования мобильных средств связи использовался специально разработанный авторский опросник и тест. Выполненное исследование показало, что среди обследованных выборок студентов у $22 \%$ фиксируется высокий уровень зависимости, у 47,5\% - средний и у $30,5 \%$ - низкий. При этом также установлено, что между студентами, имеющими разные уровни зависимости, установлены достаточно существенные отличия в особенностях эмоциональной зрелости. Особенно четко эта разница прослеживается среди студентов с высоким и низким уровнями зависимости от мобильных средств коммуникации. Среди показателей эмоциональной зрелости, по которым дифференцируют студентов, наиболее информативными являются эмпатия, саморегуляция и ее интегральный показатель. Полученные данные могут быть использованы при организации профилактики и коррекции психоэмоциональной зависимости студентов от мобильных средств коммуникации.

Ключевые слова: психоэмоциональная зависимость, мобильные средства связи, студенты, эмоциональная зрелость.

Олексій Якович Чебикін, доктор психологічних наук, професор, академік, Південноукраїнський національний педагогічний університет імені К. Д. Уиинського, вул. Старопортофранківська, 26, м. Одеса, Украӥна

\section{ПСИХОЕМОЦЙНА ЗАЛЕЖНІСТЬ ВІД МОБІЛЬНИХ ЗАСОБІВ ЗВ'ЯЗКУ У СТУДЕНТІВ, ЩО МАЮТЬ РІЗНІ ПРОЯВИ ЕМОЦІЙНОЇ ЗРІЛОСТІ}

Статтю присвячено проблемі психоемоційної залежності студентів від мобільних засобів зв’язку. Автор виходив із наступної гіпотези: оскільки емоційна зрілість особистості є інтегральною властивістю, яка інтегрується практично з усіма особливостями психіки, вона найбільшою мірою буде характеризувати наявність тієї чи іншої психоемоційної залежності. Для дослідження особливостей залежності студентів від використання мобільних засобів зв'язку використовувався спеціально розроблений авторський опитувальник і тест. Виконане дослідження показало, що серед обстежених вибірок студентів у 22\% фіксується високий рівень залежності, у 47,5\% - середній і у 30,5\% - низький. При цьому також встановлено, що студенти, які мають різні рівні залежності, досить істотно відрізняються за особливостями емоційної зрілості. Особливо чітко ця різниця простежується між студентами 3 високим і низьким рівнями залежності від мобільних засобів комунікації. Серед показників емоційної зрілості, за якими диференціюють студентів, найбільш інформативними є емпатія, саморегуляція та іiі інтегральний показник. Отримані дані можуть бути використані під час організації профілактики та корекції психоемоційної залежності студентів від мобільних засобів комунікації.

Ключові слова: психоемоційна залежність, мобільні засоби зв'язку, студенти, емоційна зрілість.

Подано до редакичї 09.11.2016 